\title{
Wages and Employs for Non-Farm Agricultural Activities: One Livelihood Strategy in Nicaragua
}

By Carlos Alberto Zuniga González \& José Luis Jaramillo Villanueva

National Autonomous University of Nicaragua Abstract - This article analyzes the indexes for nonfarm agricultural activities, which combine agricultural activities with both employment and wage. They were made with panel data of Living Measurement Standard Survey (1993, 1998, 2001 and 2005) and they were processed with econometric model as parametric technique (Binary dependent variable model).

The indexes trend was explained by a combining between nonfarm and farming agricultural activities. In summary, as soon as the economic public policy makers apply preventive measure in the labour market, while the indexes for nonfarm agricultural activities are growing up. In fact, the small farmers use the first, second and third nonfarm employ as livelihood strategy for reducing the restrictive public policy. (Unemployment).

Keywords: Nonfarm agricultural activities, Parametric Technique, Unemployment, livelihood strategy.

GJMBR Classification : JEL Code : J43, J64, J78

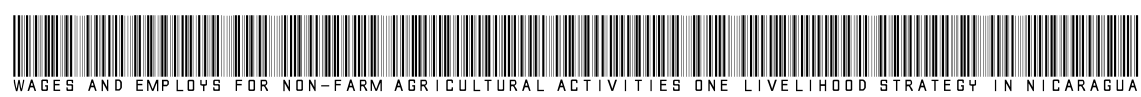

Strictly as per the compliance and regulations of:

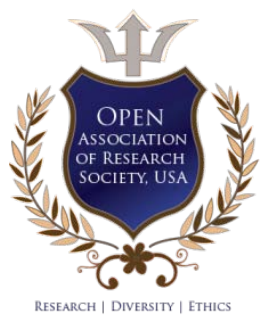

(C) 2012. Carlos Alberto Zuniga González \& José Luis Jaramillo Villanueva. This is a research/review paper, distributed under the terms of the Creative Commons Attribution-Noncommercial 3.0 Unported License http://creativecommons.org/licenses/by$\mathrm{nc} / 3.0 /$ ), permitting all non-commercial use, distribution, and reproduction in any medium, provided the original work is properly cited. 


\title{
Wages and Employs for Non-Farm Agricultural Activities: One Livelihood Strategy in Nicaragua
}

\author{
Carlos Alberto Zuniga González ${ }^{\alpha}$ \& José Luis Jaramillo Villanueva ${ }^{\sigma}$
}

\begin{abstract}
This article analyzes the indexes for nonfarm agricultural activities, which combine agricultural activities with both employment and wage. They were made with panel data of Living Measurement Standard Survey (1993, 1998, 2001 and 2005) and they were processed with econometric model as parametric technique (Binary dependent variable model).

The indexes trend was explained by a combining between nonfarm and farming agricultural activities. In summary, as soon as the economic public policy makers apply preventive measure in the labour market, while the indexes for nonfarm agricultural activities are growing up. In fact, the small farmers use the first, second and third nonfarm employ as livelihood strategy for reducing the restrictive public policy. (Unemployment)

Keywords: Nonfarm agricultural activities, Parametric Technique, Unemployment, livelihood strategy.
\end{abstract}

\section{INTRODUCTION}

N icaragua is a prominent agricultural country, such as the $28.1 \%$ of the GDP, the $15.9 \%$ of the total exports, and the $42.6 \%$ of the national employment is given by agricultural sector. The mean features of small farmers are: a) They represent the 80 $\%$ as of total farmers, while they are owner of $24 \%$ as of total land; b) They are $80 \%$ men and $20 \%$ are women, c) They have only $0.02 \%$ a basic education; d) They have $46 \%$ title deed, $16 \%$ without title deed, $13 \%$ in process of legalization, and the rest other form of possession (NIID, III CENAGRO: 2001). The importance of this study is focused in explain why does Nicaragua being an agricultural country then the workers were looking for other alternatives on nonfarm agricultural activities. This problem was reflected by the migration to town, or other neighbor Central American countries and the rural household need to generate wage and employ when the public policy measure was applied.

The study used the binary dependent variable model to measure the agricultural activities and nonfarm agricultural activities when the public policies were applied over the 1993-2005 period.

The paper is structured as follows. The next section reviews the empirical studies conducted for the community of agricultural economists. Methodology is presented in Section 3, results of research are showed

Author a : National Autonomous University of Nicaragua, León. Livestock Campus: AgroecologyDepartment.Technology and Sciences Faculty.

E-mail.czuniga@unanleon.edu.ni,czunigagonzales@gmail.com Author $\sigma$ : Colegio de Postgraduados, Campus Puebla-México. E-mail : jjaramil301@yahoo.es in section 4, and conclusion and discussion is showed in section 5 .

\section{Empirical Studies: Rnfe and RnFW ${ }^{1}$}

In the reviews of empirical studies we find that some studies were based in the concept of rural, nonfarm agricultural, non-farm income, and non-farm employment. Others authors explain the relation between rural employ and non-farm income, the mitigation process of rural poverty, of transformation farming and livestock sector, and transformation modern rural sector. Even they discussed the trend both employ and non-farm income. They also discussed the kind difference both employ and income non-farm.

The concept "non-farm agricultural" was generated by rural farmers in secondary and tertiarysectors where RNFE and RNFW was employed and income indexed (Berdegué et al., 2000), other authors define it as derive of rural area which define the rural non-agricultural economy (RNFAE): activities and incomes. The RNAE is often defined as including all economic activities in rural areas except agriculture, livestock, hunting and fishing (Lanjouw and Lanjouw, 1997). More over "Non- Farm" is defined as being all those diverse activities associated with waged work or self-employment in work that is not agriculture but located in rural areas (David and Pearce, 2000). During period 1950 the 54 per cent was busy in agricultural activities from the rural sector of Latin America, however in 1990 only 25 per cent was in it (Milicevic, 2000). This was explained by both ruralurbanmigrations and framework change in rural labour market.

The past investigations in some countries show that RINFA is a high and increase ratio of the total rural poor household in last decade (Berdegué et al., 2000). It is a strategies livelihood ${ }^{2}$. The both RNFE and RNFW are part of it.

On the other hand, analysis of rural regions of the EU can point to issues of importance for the transitions economies. Outside Central Europe this studies in this field are now being undertaken, since it is recognized that in the longer term the development of the rural non-farm sector is critical factor in providing ruralemployment and income (Bleahuand Janowski,

\footnotetext{
${ }^{1}$ RNFE, rural non-farm employs; RNFW, Rural non-farm wage, please see the table 2 for other definitions.

2 The concept of livelihood used in this paper is that given by Ellis (1999, p.6): "A livelihood comprises incomes in cash
} 
and in kind; the social relations and institutions that facilitate or constrain individual or family standards of living; and access to social and public services that contribute to the well-being of the individual or family." 2001; Breischopf and Schreider, 1999; Deichmann and Henderson, 2000; Chaplin, 2000; Sarris et al., 1999).

In countries such as Romania, where agriculture is acting as a buffer against unemploymentand hidden unemployment is widespread and increasing ( $\mathrm{Da}$ vis and Pearce, 2000), so RNAE is important for poverty reduction.

\section{a) Binary dependent variable model}

In this class of models, authors discuss estimation methods for several qualitative and limited dependent variables models. Some software provides estimation routines for binary or ordered (probit, logit, gompit) censored or truncated (Tobit, etc.), and integer valued (count data) models.

Standard introductory discussion for the models presented in this section may be found in Greene(1997), Johnston and DiNardo (1997), and Maddala (1983). Wooldridge (1996) provides an excellent reference for quasi-likelihood methods and count models.

In this class of models the dependent variable, $y$ may take on only two values-y might be a dummy variable representing the occurrence of an event, or a choice between two alternatives. For example, you may be interested in modeling the employment status of each individual in your sample (whether employed or not). The individuals differ in age, educational attainment, race, marital status, and other observable characteristics, which can be denote as $x$. The goal is to quantify the relationship between the individual characteristic and the probability of being employed.

\section{ili. Methodology}

This model was used because the study is focused in the employment behavior. I was interested in modeling the employment status of each Working Economic Population (more than 10 year and less than 60 year).

In the binary dependent variable $y$ model, the dependent variable, may take on only two values $0-1 y$ might be a dummy variable representing the occurrence of an event (in our case is employment), or a choice between two alternatives: employ in agricultural activities or employ in nonfarm agricultural activities. Suppose that we model the probability of observing a value of one as:

$$
\operatorname{Pr}\left(y_{i}=1 / x_{i}, \beta\right)=1-F\left(-x_{i}^{\prime} \beta\right)
$$

where $F$ is a continuous, strictly increasing function that takes a real value and returns a valueranging from zero to one. The choice of the function $\mathrm{F}$ determines the type of binary model. Itfollows that:

$$
\operatorname{Pr}\left(y_{i}=0 / x_{i}, \beta\right)=F\left(-x_{i}^{\prime} \beta\right)
$$

Given such a specification, we can estimate the parameters of this model using the method of maximum likelihood. The likelihood function is given by:

$$
l(\beta)=\sum_{i=0}^{n} y_{i} \log \left(1-F\left(-x_{i}^{\prime} \beta\right)\right)+\left(1-y_{i}\right) \log \left(F\left(-x_{i}^{\prime} \beta\right)\right.
$$

The first order conditions for this likelihood are nonlinear so that obtaining parameter estimates requires an iterative solution. I use Eviews 5.1 that by default, it uses a second derivative method for iteration and computation of the covariance matrix of the parameter estimates. There are two alternative interpretations of this specification that are of interest. First, the binary model is often motivated as a latent variables specification. Suppose that there is an unobserved latent variable.

$$
\begin{aligned}
& \qquad y_{i}^{*}=x_{i}^{\prime} \beta+\mu_{i} \quad \text { (4) } \\
& \qquad \operatorname{Pr}\left(y_{i}=1 / x_{i}, \beta\right)=\operatorname{Pr}\left(y_{i}^{*}>0\right)=\operatorname{Pr}\left(x_{i}\right) \\
& \text { where ' is the cumulative distribution function of } \\
& \mu \text {. Common models include probit (standardnormal), } \\
& \text { logit, (logistic), and gompit (extreme value) specification } \\
& \text { for the } \mathrm{F} \text { function. In principle, the coding of the two } \\
& \text { numerical values of } \mathrm{y} \text { is not critical since each of the }
\end{aligned}
$$
for the $F$ function. In principle, the coding of the two binary responses only represents an event. whereis a random disturbance. Then the observed dependent variable is determined by whether* exceeds a threshold value:

$$
y_{i}=\left\{\begin{array}{lll}
1 & \text { if } & y_{i}^{*}>0 \\
0 & \text { if } \quad y_{i}^{*} \leq 0
\end{array}\right.
$$

In this case, the threshold is set to zero, but the choice of a threshold value is irrelevant, so long as a constant term is included in . Then:

$$
\operatorname{Pr}\left(y_{i}=1 / x_{i}, \beta\right)=\operatorname{Pr}\left(y_{i}^{*}>0\right)=\operatorname{Pr}\left(x_{i}^{\prime} \beta+\mu_{i}>0\right)=1-F_{\mu}\left(-x_{i}^{\prime} \beta\right)
$$

Nevertheless, Eviews require that I code y as zero-one variable. This restriction yields a number of advantages. For one, coding the variable in this fashion implies that $y$ $=1$.

\footnotetext{
3 See table No 1 that show exchange ratios, annual inflation, farm sample and description variable.
} 


$$
\begin{aligned}
E\left(\frac{y_{i}}{x_{i}}, \beta\right) & =1 \cdot \operatorname{Pr}\left(y_{i}=1 / x_{i}, \beta\right)+0 \cdot \operatorname{Pr}\left(y_{i}=\frac{0}{x_{i}}, \beta\right) \\
& =\operatorname{Pr}\left(y_{i}=\frac{1}{x_{i}}, \beta\right)
\end{aligned}
$$

This convention provides us with a second interpretation of the binary specification as a conditional mean specification. It follows that we can write the binary model as a regression model:

$$
y_{i}=\left(1-F\left(-x_{i}, \beta\right)+\epsilon_{i}\right.
$$

where $\epsilon_{i}$ is a residual representing the deviation of the binary $y_{i}$ from its conditional mean. Then:

$$
\begin{aligned}
& E\left(\epsilon_{i} / x_{i}, \beta\right)=0 \\
& \operatorname{Var}\left(\epsilon_{i} / x_{i}, \beta\right)=0 \quad F\left(-x_{i}^{\prime} \beta\right)\left(1-F\left(-x_{i}^{\prime} \beta\right)\right) .
\end{aligned}
$$

As Eviews requires code dependent variable, it is coding as a zero-one. One if the farm employs working economic population in agricultural activities, zero if the farm no employs it. In the other hand, there are two groups for coding independent variable. The first group is for wage and the second is for employ. The first it is coding as salary index, the calculation for is as follows:

$$
x_{i}=\sum_{k=1}^{n} \alpha_{k} * I_{k}
$$

Where, $x_{i}$ is the monthly real wage index of each farm; $\alpha_{k}$ is the weightier of either farm or nonfarm agricultural activity " $\mathrm{K}$ " and finally $I_{k}$ is the simple index for the farm activity " $K$ ".

The weightier by each farm activity is getting of divide it between the total farm wages in a year. It is as follow:
Where, $\alpha_{k}$ is the participation of each farm activity in the total earnings; $;<=)(>)$ is the income of each farm activity " $K$ "; and ?@? $<A ;<=)$ is the total wage.

The simple index of each farm activity " $\mathrm{K}$ " is gotten to divide the average salary between farm activities in a month during a current period and the average annual of even it in the base year (Central Bank of Nicaragua, 1994).

The data source is the household survey named Living Standard Measurement Survey $\left(\mathrm{LSMS}^{4}\right)$ of the National Institute of Information and Development (NIID). Hence, I make the both six wage and six employ indicators (See table 1 and 2).

To estimate a binary dependent variable model, I choose third method: Probit, Logit and Gompit. For Probit:

$$
\operatorname{Pr}\left(y_{i}=1 \mid x_{i}, \beta\right)=1-\emptyset\left(-x_{i}^{\prime} \beta\right)=\emptyset\left(x_{i}^{\prime} \beta\right)
$$

$$
\alpha_{k}=\frac{W A G E(k)}{\text { TOTALWAGE }}
$$

where $\emptyset$ is the cumulative distribution function of the standard normal distribution. For Log it:

$$
\begin{aligned}
\operatorname{Pr}\left(y_{1}=1 \mid x_{i}, \beta\right) & =1-\left(e^{-x_{i}^{\prime} \beta /}\left(1+e^{-x_{i}^{\prime} \beta}\right)\right) \\
& =e^{-x_{i}^{\prime} \beta /}\left(1+e^{-x_{i}^{\prime} \beta}\right)
\end{aligned}
$$

where is based upon the cumulative distribution function for the logistic distribution. for Gompit

$$
\begin{aligned}
\operatorname{Pr}\left(y_{i}=1 \mid x_{i}, \beta\right) & =1-\left(1-\exp \left(-e^{x_{i}^{\prime} \beta}\right)\right) \\
& =\exp \left(-e^{x_{i}^{\prime} \beta}\right)
\end{aligned}
$$

\footnotetext{
${ }^{4}$ Living Standards Measurement Survey (LSMS), is widely recognized as a leader in introducing and improving integrated household surveys in developing countries. The LSMS has been an important effort of the World Bank Development Research Group (DECRG) for more than 20 years (World Bank, 2006)
} 
which is based upon the CDF for the Type-1 extreme value distribution is skewed.

Table 1: Exchange rate, Annual inflation and farm sample

\begin{tabular}{|l|l|l|l|}
\hline LSMS Years & $\begin{array}{l}\text { Exchange rate } \\
\text { C\$x US }\end{array}$ & $\begin{array}{l}\text { Annual } \\
\text { Inflation (\%) }\end{array}$ & $\begin{array}{l}\text { Farm } \\
\text { sample }\end{array}$ \\
\hline 1993 & 6.35 & 19.5 & 11,121 \\
\hline 1998 & 11.1938 & 18.5 & 11,610 \\
\hline 2001 & 13.8408 & 4.7 & 19,755 \\
\hline 2005 & 17.1455 & 9.58 & 19,325 \\
\hline
\end{tabular}

Table 2 : Coding variables of binary dependent variable model

\begin{tabular}{|l|c|l|}
\hline Code & Variable & Description \\
\hline WEP & $y_{i}$ & Working economic population (more than 10 year and less than 60 year) \\
\hline RMEA & $x_{1}$ & Rural mean employ in farm agricultural activity \\
\hline RMENFA & $x_{2}$ & Rural mean employ in nonfarm agricultural activity \\
\hline RMWAI & $x_{3}$ & Rural mean wage index in farm agricultural activity \\
\hline RMWNFAI & $x_{4}$ & Rural mean wage index in nonfarm agricultural activity \\
\hline RSEA & $x_{5}$ & Rural second employ in farm agricultural activity \\
\hline RSENFA & $x_{6}$ & Rural second employ in nonfarm agricultural activity \\
\hline RSWAI & $x_{7}$ & Rural second wage index in farm agricultural activity \\
\hline RSWNFAI & $x_{8}$ & Rural second wage index in nonfarm agricultural activity \\
\hline RTEA & $x_{9}$ & Rural third employ in farm agricultural activity \\
\hline RTENFA & $x_{10}$ & Rural third employ in nonfarm agricultural activity \\
\hline RTWAI & $x_{11}$ & Rural third wage index in farm agricultural activity \\
\hline RTNFAI & $x_{12}$ & Rural third wage index in nonfarm agricultural activity \\
\hline
\end{tabular}

\section{Results 5}

The aim in this paper was the employment and wage status study over 1993-2005 periods, when the minimal salary was applied on the rural sector.

\section{a) Employment}

The stability of the work force scored important changes on your structure, over the period 1990-1994. It was resulting of the army reduction, conciliation plan of the country, sector public reduction through application conversion occupational plan, labour mobilization plan, and privatization enterprise process of the area people ownership. (Central Bank of Nicaragua: 1994-93)

With the discussion above mentioned, one livelihood strategies was used in Nicaragua as second and third employ in nonfarm agricultural activities, over 1993 to 2005 period,. They were RSENFAI, RTENFAl as an index of it, in contrast RMENFAl was higher than RMEA in 1993; therefore it was lower than RMEA during 1998 to 2005. The working population was employed on mean rural agricultural activity, however RSENFA (-0.78 probit, -1.62 logit and -1.59 gompit) was negative for 1993, until 2005 it reachs 1.14 probit, 1.99 logit and 2.02 gompit. So, the third nonfarm agricultural activity (RTENFA) appears as livelihood strategy. It has an increase trend. For 1993 to 2005 the ratios of them are: probit 1.08, logit 0.66, gompit0.58. (See Table No 3 and 4). A possible explication to these ratios may be the economic policy made for the government. For example: during 1998, Nicaragua had an incident as consequence of hurricane Mitch, for the next year, as a result increase the public investment in infrastructure to manage reconstruction of bridge, highway, school, center health, and household destroyed by Agricultural, construction and trade sectors were that more contribution in generation employs (82 per cent in 1999) (Central Bank of Nicaragua: 1999).

Employ showed unfavouravlebehaviour in 2001. It was caused by: a) slowing down of theactivity economic, it was reflected by fall of the GDP grown of 2.5 points less than past year, b) supply increase of labour force, and c) employ informal increased that absorbed part of unemployment hand work due to decrease activity formal sector. (Central Bank of Nicaragua: 2001)

In 2005, the generation of employ shows upper dynamism than activity economic. 107,800were the new position work, and the increase ratio was 5.5 per cent, regarding to November 2004. (Central Bank of Nicaragua: 2005)

\section{b) Salary}

The indexes for wage show a varied behavi our. The wage in nonfarm agricultural activitieshad a great weight in 1993. Therefore RMWNFAl, RSWNFAI, RTWNFAI had highest index. In fact, for 1990 the wage(s) policy was focused in deregulation of labour market, consequently it was allowance eliminated, efficiency and productivity worker gave. Hence, it was freezed wage policy and reduction public sector until

\footnotetext{
${ }^{5}$ See table No 3 and No 4, Fig 1-4
} 
1994 (Central Bank of Nicaragua: 1994). In contrast, the wage in agricultural activities is highlighted as RMWAl, RSWAI in 1998, although the RTWNFAl was exception.

For 2001, RSWNFAl was unique index in nonfarm agricultural activities. Now that during 2001, paradoxically real wage to experience a recovery of 7.8 per cent, in contrast slowing down of activity economic and the low average productivity of input work factor. Your increase is mean due by low inflation that kept up this year. The business about the minimum legal wage was made in February of this year, as result modest increase of 12 per cent in each and every one of sector economics, but the livestock and crop sector was the exception, where wages increase 22.2 per cent. This sector shows a basket cover of 47.7 per cent, if we use as reference urban basket, however it increases 112 per cent, if we use the cost basket rural. (Central Bank of Nicaragua: 2001)

For 2005, only RSWAI is an index representative of agricultural activities. However, RMWNFAl and RTWNFAl are significant of nonfarm agricultural activities. In 2005 the average national wage shows an increase of 15.5 per cent (8.8 percent in November 2004). The minimum legal wage was agreement in mayo 2005 , as result increase of 16.5 per cent in construction and financial activity, and 15 per cent in rest activities. Even the commission tripartite check the rule of the coffee, so they agreement minimum legal wage to 26.6 per cent (7.9 per cent in 2004). (Central Bank of Nicaragua: 2005).

\section{Conclusions and Discussion}

The results evidence that employment in nonfarm agricultural activities were one livelihood strategy for rural household, where the mean employment in nonfarm agricultural activity was significant over 1993; the second employ was significant in agricultural nonfarm activity over 2005. The coefficients seem steady and significant for probit, logit and gompit estimation.

Regarding the wages indexes the situation is similar. The mean, second and third wage were innonfarm agricultural activities and they had a great weigh over the period studied. The indexes are similar for logit, probit and gompit estimation.

The results were consistent with the public policy data when they had reduced the employ and wage for rural sector, the economic population increase your respective employ and wage in second and third nonfarm agricultural activities, as show the table 2 results.

\section{References Références Referencias}

1. Berdegué J.A, Reardon, Thomas., Escobar Germán, (2000). Empleo e ingresoRurales No Agíricolas en (2000). Empleo e ingresoRurales No Agíricolas en
América Latina y el Caribe, Documentopresentado en la conferencia "Development of the Rural Economy and Poverty Reduction in Latin America and the Caribbean. New Orleans, Louisiana, March 24,2000 , in conjunction with the annual meeting of Board of Governors of the Inter-American Devolopment Bank (IDB) and the Inter- American Investment Corporation.

2. Breitschopf B and Schreider G (1999). Rural development in transition economies - the cases of two counties in Romania. Paper presented at the 48th International Atlantic Economic Conference 710 October, Montreal.

3. Bleahu, A., and Janowski, M, (2001). Factors affecting Household-level involvement in Rural-onFarm Economic Activities in two communities in Dolj and Brasov judete, Romania (unpublished mimeo).

4. Central Bank of Nicaragua (1993). Annual Report, pp53-63

5. Central Bank of Nicaragua (1994). Annual Report, pp55-62

6. Central Bank of Nicaragua (1999). Annual Report, pp23-35

7. Central Bank of Nicaragua (2001). Annual Report, pp32-40

8. Central Bank of Nicaragua (2004). Methodological Notes. Economic Indexes, pp79-83

9. Central Bank of Nicaragua (2005). Annual Report, pp32-40

10. Chaplin, H. (2000). Agricultural Diversification: A Review of Methodological Approaches and Empirical Evidence. Imperial College at Wye, University of London: IDARA Working Paper Series 2/2.

11. Davis, JR and Pearce, D., (2000). The NonAgricultural Rural Sector in Central and Eastern Europe, forthcoming in Lerman, Z and Csaki, C. (2001) 'The Challenge of Rural Development in the EU Accession Process' World Bank Technical Publication.

12. Deichmann, U. and V. Henderson. (2000). Urban and Regional Dynamics in Poland, World Bank Policy Research Working Paper No 2457.

13. Ellis, F. (1999). Rural livelihood diversity in developing countries: evidence and policy implications. Natural Resource Perspectives, Number 40 (April). London: Overseas Development Institute.

14. Greene, William H. (1997). Econometric Analysis, 3rd. Edition, Upper Saddle River, NJ: Prentice Hall.

15. Johnston, Jack and John Enrico DiNardo (1997). Econometric Methods, 4th Edition, New York McGraw-Hill

16. Lanjouw JO and Lanjouw P (1997). The rural nonfarm sector: an update. Paper presented at the XXIII International Conference of Agricultural Economist
(IAAE) on Food security, diversification and International Conference of Agricultural Economist
(IAAE) on Food security, diversification and

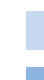$$
\text { - }
$$

.

.


resource management: refocusing the role of agriculture 10-16 August, Sacramento, USA.

17. Maddala, G.S. and S. Wu (1989). A comparative Study of Unit Root Test with Panel Data and a New Simple Test, Oxford Bulletin of Economics and Statistic, 61: 631-52

18. Mendoza, J. A. (1999). El empleo rural no agropecuario en México. Ponencia al Seminario Latinoamericanosobre Desarrollodel Empleo Rural No Agrícola, Santiago, Chile, Septiembre 1999, BIDFAO-CEPAL-RIMISP.

19. Milicevic, Xilena (2000). Empleo eingresosrurales no agrícolas en América Latina.

20. National Institute of Information and Development (2001). Third Census National Agricultural.

21. National Institute of Information and Development (2001). Leaving Standards Measurement Survey, 2001

22. Sarris, AH, Doucha T, and Mathijs E (1999). Agricultural Restructuring in Central and Eastern Europe: Implications for Competitiveness and Rural Development. European Review of Agricultural Economics, 305-329

23. World Bank, (2006). LSMS IV: Research for Improving Survey Data. Poverty Group. DECRG. January 2006.

24. Wooldridge, Jeffrey M. (1997). A Note on the Lagrange Multiplier and F-statistic for Two Stage Least Square Regressions, Economics Letters, 34: 151-155. 

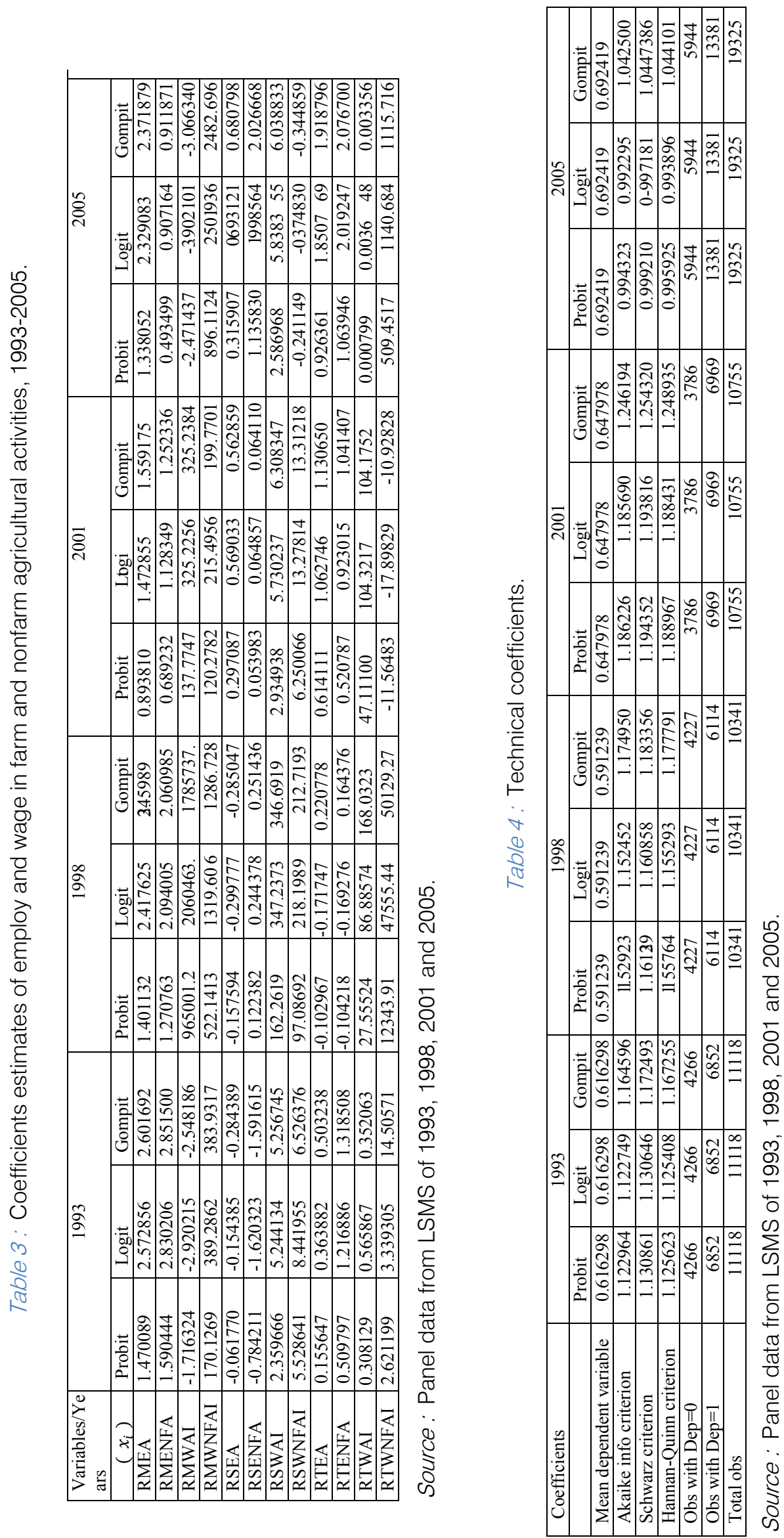
Figure 1: Employ indexes 1993-2005.

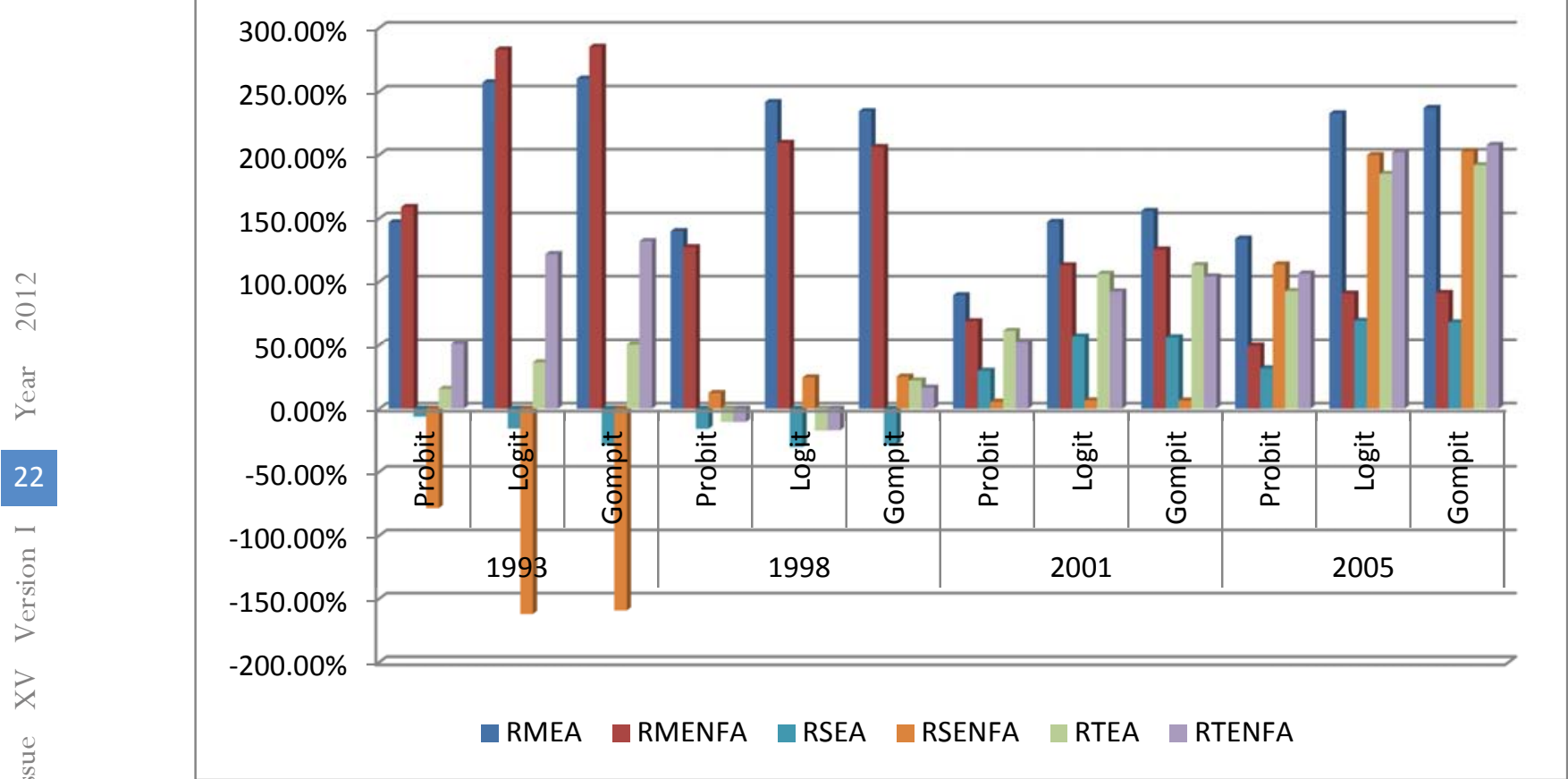

Figure 2: Real wage indexes 1993-2005.

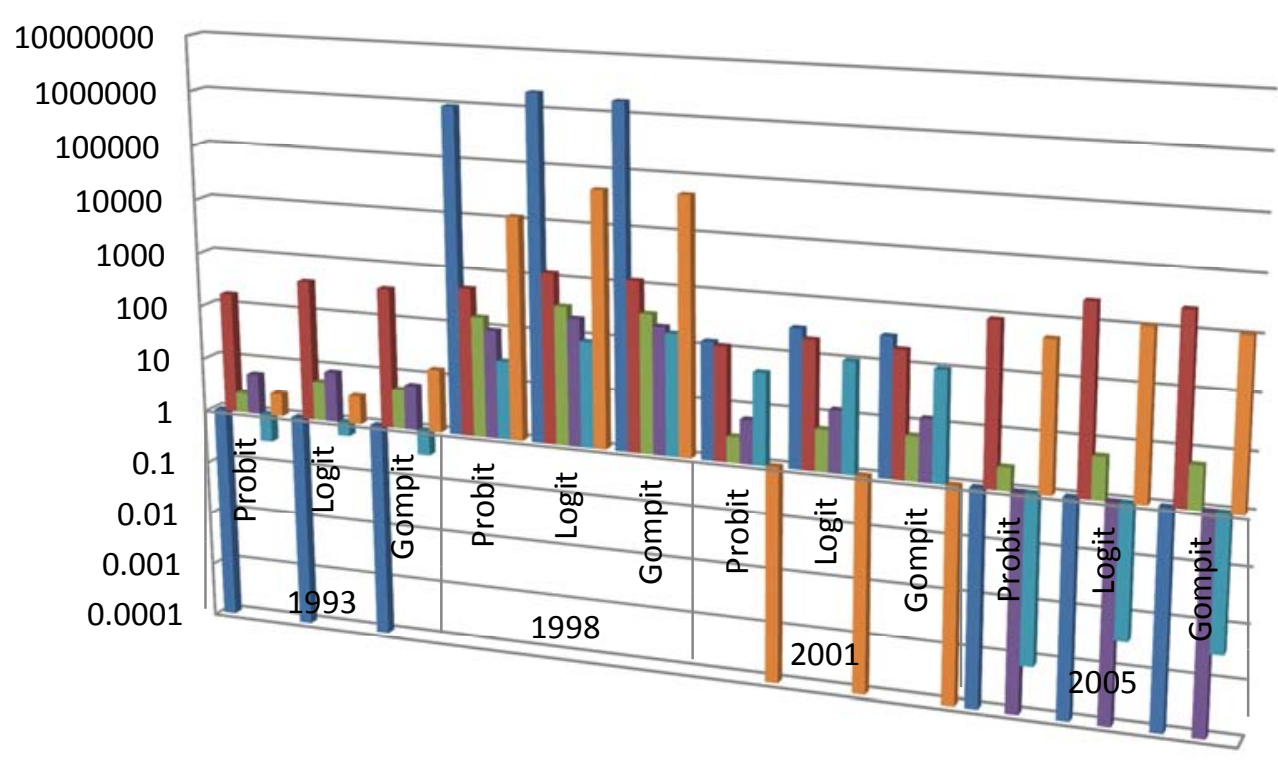

$\square$ RMWAI $\square$ RMWNFAI $\square$ RSWAI $\square$ RSWNFAI $\square$ RTWAI $\square$ RTWNFAI 
Figure 3 : Employ indexes $1993-2005$.
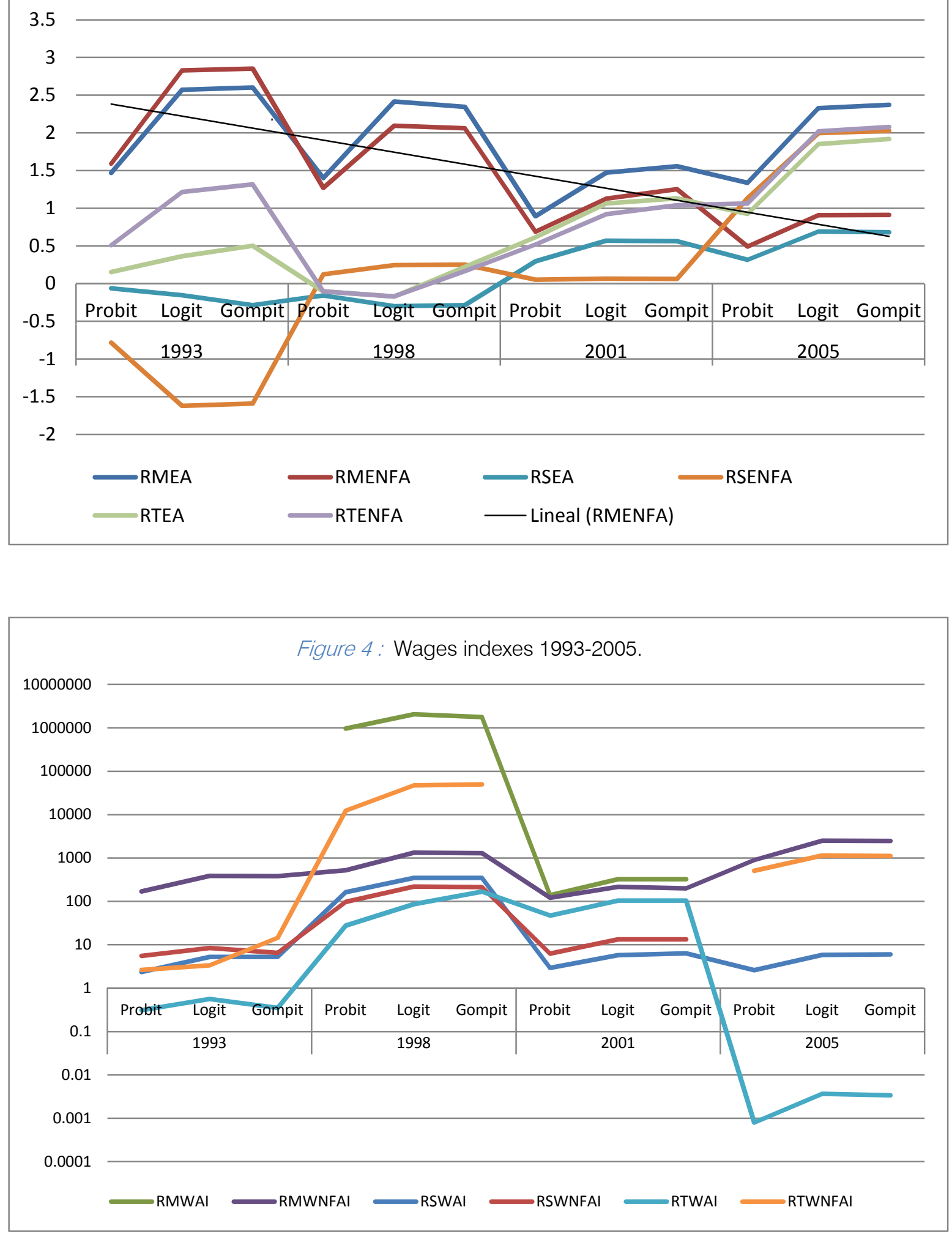